\title{
Distribution of Qol Resistance in Populations of Tangerine-Infecting Alternaria alternata in Florida
}

\author{
Byron Vega and Megan M. Dewdney, Citrus Research and Education Center, University of Florida, Lake Alfred
}

\begin{abstract}
Vega, B., and Dewdney, M. M. 2014. Distribution of QoI resistance in populations of tangerine-infecting Alternaria alternata in Florida. Plant Dis. 98:67-76.

Chemical control, based on copper and quinone outside inhibitor (QoI) fungicides, has been essential for the management of brown spot of citrus, caused by Alternaria alternata. However, QoI control failures were detected recently in Florida. From 2008 to 2012, 817 monoconidial isolates of A. alternata from 46 citrus orchards were examined for sensitivity to azoxystrobin (AZ) and pyraclostrobin (PYR). Of the isolates, $57.6 \%$ were resistant to both fungicides, with effective concentration to inhibit $50 \%$ growth $\left(\mathrm{EC}_{50}\right)$ values greater than $5 \mu \mathrm{g} / \mathrm{ml}$ for $\mathrm{AZ}$ and $1 \mu \mathrm{g} / \mathrm{ml}$ for PYR. The mean $\mathrm{EC}_{50}$ values for sensitive isolates were 0.139 and $0.020 \mu \mathrm{g} / \mathrm{ml}$ for $\mathrm{AZ}$ and PYR, respectively. The $\mathrm{EC}_{50}$ values of both fungicides were highly correlated $(P<0.0001)$, indicating cross resistance. The proportion of resistant isolates differed sig-

nificantly $(P<0.0001)$ among cultivars and with QoI application frequency $(P<0.0001)$. However, resistance was not significantly related $(P=0.364)$ to disease severity in the field (low, moderate, and high) or isolate virulence $(P=0.397)$. The molecular basis for $\mathrm{QoI}$ resistance was determined for a subset of 235 isolates using polymerase chain reaction restriction fragment length polymorphism of the cytochrome $b$ gene. All resistant isolates showed the point mutation G143A. Based on the presence of one or two introns, isolates were classified as profile I and profile II, respectively. The resistance frequency was significantly higher $(P<0.0001)$ in isolate profile II, suggesting a higher selection pressure for resistant population profile II.
\end{abstract}

Alternaria brown spot (ABS), caused by Alternaria alternata (Fr.:Fr.) Keissl., is a serious disease of tangerine cultivars (Citrus reticulata Blanco) and their hybrids in commercial citrus orchards in humid subtropical and semiarid growing regions (58). This fungus produces the host-selective ACT toxin $(32,33)$, which plays an important role in host specificity and isolate virulence $(23,34)$. Florida has 7,000 ha of tangerine and tangerine hybrids for freshfruit production (21). More than two-thirds of the tangerine cultivars planted in Florida are susceptible to ABS, including 'Minneola', 'Nova', and 'Orlando' tangelo; 'Dancy' and 'Sunburst' tangerine; 'Murcott' tangor, and some Dancy hybrids such as 'Lee' (56). The fungus can affect leaves, twigs, and young fruit, cause considerable yield loss, and produce blemishes on fruit that reduce marketability $(56,58)$.

Management of ABS includes the use of cultural methods such as disease-free nursery stock, wide tree spacing, reduction of excessive vegetative growth, the elimination of overhead irrigation, and fungicide applications (16,57). Although cultural practices reduce disease severity, ABS control is largely dependent on fungicide applications $(8,16,56)$. Copper-based fungicides (Fungicide Resistance Action Committee [FRAC] code M1), ferbam (FRAC code M3), and quinone outside inhibitors (QoIs; FRAC code 11) have been widely used in Florida over the last decade. Recently, Pristine (pyraclostrobin [QoI] + boscalid [FRAC code 7]) and Quadris Top (azoxystrobin [QoI] + difenoconazole [FRAC code 3]) were registered for use in citrus, increasing the options for fungicide rotations. To optimize fungicide applications for ABS control, a weather-based model (Alter-Rater) was developed $(8,55)$; however, due to the complexity of some environmental

Corresponding author: M. M. Dewdney, E-mail: mmdewdney@ufl.edu

* The $\boldsymbol{e}$-Xtra logo stands for "electronic extra" and indicates that a supplementary figure is available in the online edition.

Accepted for publication 9 July 2013.

http:dx.doi.org/10.1094/PDIS-04-13-0449-RE

(C) 2014 The American Phytopathological Society variables (difficulty in accurately measuring leaf wetness) used for the model, this has not been extensively adopted by growers. In Florida, growers may apply 2 to 15 fungicide sprays during the course of the growing season, depending on host susceptibility and weather conditions.

In general, QoI fungicides have a broad spectrum of activity against plant-pathogenic fungi. This includes the most important taxonomic groups; namely, Ascomycetes, Basidiomycetes, Deuteromycetes, and Oomycetes $(5,6)$. QoI fungicides are classified as high risk for resistance development due to the site-specific mode of action. The QoI fungicides block electron transfer between cytochrome $b$ and cytochrome $c$ by binding to the quinol oxidation (Qo) site of the mitochondrial cytochrome $b c_{l}$ enzyme complex, which is a key component of the respiratory electron transfer chain $(6,61)$. Resistance to QoI fungicides was first reported in Blumeria graminis f. sp. tritici (wheat powdery mildew) in Germany in 1988 (6). Thereafter, resistance was observed in many countries around the world among pathogens that affect many crops, including Mycosphaerella fijiensis in banana (52), Plasmopara viticola in grape (11), Venturia inaequalis in apple (35), Podosphaera fusca and Pseudoperonospora cubensis in cucumber (28), and A. alternata in pistachio (40).

A target site mutation of the cytochrome $b$ gene, resulting in a specific amino acid substitution, prevents fungicide binding at the target site and causes QoI resistance (6). Three amino acid substitutions in the cytochrome $b$ protein have been detected in QoIresistant plant-pathogenic fungi and oomycetes (18). The amino acid substitution from glycine to alanine at position 143 (G143A) has been reported in most of the resistant pathogens, leading to a high level of resistance (resistant factor $[R F]>100$ ). This mutation has been associated with QoI-control failures (20). The other two amino acid substitutions, from phenylalanine to leucine at position 129 (F129L) and glycine to arginine at position 137 (G137R), have been associated with moderate levels of resistance, and pathogen populations are usually controlled with recommended field rates of QoI fungicides (18,51).

In 2008, a commercial tangerine grower located in central Florida (Polk County) observed ABS control failure following several QoI applications. The isolates were screened for QoI sensitivity and a large proportion of isolates tested were QoI resistant (43). 
Several more suspected control failures were reported in 2009, leading to the hypothesis that QoI resistance of A. alternata could be widely distributed throughout the state. The objectives of this study were to determine (i) the baseline sensitivity to azoxystrobin and pyraclostrobin in A. alternata isolates never exposed to QoI fungicides, (ii) the in vitro sensitivity to azoxystrobin and pyraclostrobin of $A$. alternata isolates collected from commercial citrus orchards in Florida, and (iii) whether G143A was the mutation in the cytochrome $b$ responsible for the resistance.

\section{Materials and Methods}

Isolate collection. From 2008 to 2009, five commercial tangerine hybrid orchards, encompassing eight blocks, were sampled from central Florida. Groves were sampled based on information provided by growers about ABS control failure using QoI fungicides. A more systematic statewide survey was initiated from 2010 to 2012 in commercial tangerine and tangerine hybrid orchards in 11 tangerine-producing counties, comprising $79 \%$ of the tangerineproduction area in Florida. In 2010, 13 citrus orchards (121 ha) encompassing 18 blocks were sampled whereas, during 2011 and 2012, 12 orchards ( 125 ha in 23 blocks) and 18 orchards ( 345 ha in 29 blocks), respectively, were sampled. Disease severity was visually evaluated in the field based on symptom distribution and classified as low, moderate, and high. Low disease severity was characterized by small scattered lesions on old leaves, moderate disease severity corresponded to mild coalescing lesions on young leaves and fruit, and high disease severity showed abundant lesions in young and old leaves as well as fruit.

Samples consisted of 60 to 80 Alternaria-infected leaves or fruit arbitrarily selected per block from different trees. Samples were kept in sealed plastic bags on ice until pathogen isolation. Individual young lesions of approximately $4 \mathrm{~mm}^{2}$ were surface disinfested with $50 \%$ ethanol for $30 \mathrm{~s}$, followed by 5 min with $5 \%$ sodium hypochlorite, rinsed with sterile deionized water (SDW), blotted dry on sterile filter paper, and plated on potato dextrose agar (PDA; Becton Dickinson) amended with benomyl $(10 \mu \mathrm{g} / \mathrm{ml}$; DuPont Crop Protection), rifampicin (10 $\mu \mathrm{g} / \mathrm{ml}$; Fisher Scientific), and ampicillin $(250 \mu \mathrm{g} / \mathrm{ml}$; Fisher Scientific). Plates were incubated at $24^{\circ} \mathrm{C}$ for 5 to 7 days. Individual colonies of A. alternata were transferred to PDA overlaid with sterilized filter paper for long-term storage (45). Once the filter paper was colonized (5 to 7 days), it was lifted from the medium surface, placed in sterile coin envelopes, and dried for at least $6 \mathrm{~h}$ in a laminar-flow hood. Envelopes were stored at $-20^{\circ} \mathrm{C}$ until further studies. Conidial production for either pathogenicity or fungicide sensitivity tests was induced by transferring 4-day-old mycelia from PDA to clarified V8 agar $(100 \mathrm{ml}$ of centrifuged V8 juice, $20 \mathrm{~g}$ of agar, and $10 \mathrm{~g}$ of $\mathrm{CaCO}_{3}$ per liter). Cultures were incubated at room temperature under white fluorescent light for 7 to 12 days. Conidia were harvested by flooding the plates with 15 to $20 \mathrm{ml}$ of SDW, gently rubbing the surface, and filtering through three layers of sterile cheesecloth.
Pathogenicity tests and monoconidial isolates. To differentiate between saprophytes and other A. alternata pathotypes, pathogenicity to tangerine was confirmed by inoculating immature leaves of Minneola tangelo, Dancy tangerine, or Murcott tangor in a detached leaf in vitro spray technique, as previously described (12). In total, 1,258 A. alternata isolates were tested for pathogenicity. For each fungal isolate, three replicate leaves were sprayed with $10^{5}$ conidia/ml using a chromatography sprayer (TLC Crown North American Professional Products). Leaves were placed in racks inside a clean 30-by-20-by-10-cm humid chamber and incubated at room temperature for 2 to 3 days. Pathogenicity was evaluated after the second or third day. Isolate virulence was determined by rating the leaf area covered by lesions on a scale of 1 to 3 , where $1=<25 \%$ leaf area diseased, $2=$ between 25 and $50 \%$ leaf area diseased, and $3=>50 \%$ leaf area diseased. An isolate was considered pathogenic if at least two leaves showed symptoms 3 days after inoculation.

To produce monoconidial cultures of pathogenic isolates, $100 \mu \mathrm{l}$ of conidial suspension $\left(5 \times 10^{3}\right.$ conidia/ml $)$ was spread on $2 \%$ water agar (Becton Dickinson) and incubated in the dark at $24^{\circ} \mathrm{C}$ for 16 to $20 \mathrm{~h}$. After incubation, one germinated conidium was transferred to PDA overlaid with sterilized filter paper for longterm storage, following the procedure described above (45).

Sensitivity of $A$. alternata isolates to azoxystrobin and pyraclostrobin. In total, 817 A. alternata monoconidial isolates were tested from the 2008 to 2012 sample collections. In vitro fungicide sensitivity was determined using the resazurin-based microtiter assay, as previously described (60). Briefly, technical-grade azoxystrobin (Syngenta Crop Protection) and pyraclostrobin (BASF Corp.) were dissolved in acetone at $10 \mathrm{mg} / \mathrm{ml}$ and 10 -fold serially diluted. The final concentration of acetone in complete medium (7) was $0.1 \%$ by volume. Resazurin salt (Sigma-Aldrich) was dissolved in distilled water at $4 \mathrm{mM}$ and filter sterilized $(0.22-$ $\mu \mathrm{m}$ filter; Corning Inc.). Each isolate was added in triplicate into a 96-well, flat-bottom microplate (Corning Inc.). The final concentrations per well of either azoxystrobin or pyraclostrobin were 0 , $0.001,0.01,0.05,0.1,0.5,1$ or $10 \mu \mathrm{g} / \mathrm{ml}$ and $0,0.001,0.005,0.01$, $0.05,0.1,1$, or $10 \mu \mathrm{g} / \mathrm{ml}$, respectively. The final conidia and resazurin concentrations (per well) were $4 \times 10^{4}$ conidia/ml and $40 \mu \mathrm{M}$, respectively. Plates were covered with plastic lids, placed into a clean plastic humid chamber, and incubated in the dark at $27^{\circ} \mathrm{C}$ for $24 \mathrm{~h}$, with shaking at $400 \mathrm{rpm}$. Fungal respiration was determined by measuring the resazurin reduction at 570 and $600 \mathrm{~nm}$, as previously described (60). Absorbance was read with a microplate spectrophotometer (Bio-Rad). Isolate sensitivity was determined by the effective concentration needed to reduce resazurin by $50 \%\left(\mathrm{EC}_{50}\right)$ using either sigmoidal or exponential decay functions (60). Isolates with $\mathrm{EC}_{50}$ values for azoxystrobin and pyraclostrobin higher than 5 or $0.5 \mu \mathrm{g} / \mathrm{ml}$, respectively, were classified as resistant. Isolates with $\mathrm{EC}_{50}$ values lower than those values were classified as sensitive.

Baseline sensitivity of $A$. alternata to azoxystrobin and pyraclostrobin. In total, $40 \mathrm{~A}$. alternata isolates were obtained from the

Table 1. Baseline sensitivity of Alternaria alternata isolates from different citrus hosts to azoxystrobin and pyraclostrobin

\begin{tabular}{|c|c|c|c|c|c|c|}
\hline \multirow[b]{2}{*}{ Isolate group } & \multirow[b]{2}{*}{ Location, county } & \multirow[b]{2}{*}{ Year } & \multirow[b]{2}{*}{ Host $^{b}$} & \multirow[b]{2}{*}{$N^{\mathrm{c}}$} & \multicolumn{2}{|c|}{$\operatorname{Mean} \mathrm{EC}_{50}(\mu \mathrm{g} / \mathrm{ml})^{\mathrm{a}}$} \\
\hline & & & & & Azoxystrobin & Pyraclostrobin \\
\hline AR & Arcadia, DeSoto & 1997 & Sunburst tangerine & 4 & $0.209(0.098)$ & $0.031(0.010)$ \\
\hline CPI & Immokalee, Collier & 1996 & Murcott tangor & 3 & $0.209(0.090)$ & $0.036(0.013)$ \\
\hline $\mathrm{EV}$ & Lake Alfred, Polk & 1996 & Minneola tangelo & 4 & $0.058(0.017)$ & $0.010(0.003)$ \\
\hline FM & Fort Meade, Polk & 1996 & Minneola tangelo & 2 & $0.134(0.032)$ & $0.029(0.007)$ \\
\hline IMK & Immokalee, Collier & 1997 & Minneola tangelo & 2 & $0.148(0.192)$ & $0.027(0.033)$ \\
\hline LOR & Lorida, Highlands & 1997 & Orlando tangelo & 3 & $0.107(0.112)$ & $0.029(0.015)$ \\
\hline RAN & Immokalee, Collier & 1997 & Sunburst tangerine & 5 & $0.070(0.039)$ & $0.015(0.008)$ \\
\hline $\mathrm{SH}$ & Polk City, Polk & 1996 & Minneola tangelo & 6 & $0.178(0.127)$ & $0.032(0.017)$ \\
\hline VB & Vero Beach, Indian River & 1997 & Grapefruit & 6 & $0.167(0.121)$ & $0.020(0.013)$ \\
\hline WP & West Palm Beach, Palm Beach & 1996 & Minneola tangelo & 5 & $0.082(0.043)$ & $0.010(0.006)$ \\
\hline
\end{tabular}

${ }^{\mathrm{a}} \mathrm{EC}_{50}=$ effective concentration needed to reduce fungal growth by $50 \%$. Values in parentheses denote standard deviation.

b Tangerine $=$ Citrus reticulata, tangor $=C$. reticulata $\times$ C. sinensis, tangelo $=C$. paradisi $\times$ C. reticulata, and grapefruit $=C$. paradisi .

c Number of isolates tested. 
Dewdney lab culture collection (Table 1). These isolates were collected from tangerine hybrids and grapefruit groves where there was no history of QoI fungicide applications prior to 2000. Sensitivity to azoxystrobin and pyraclostrobin was determined using the resazurin-based microtiter assay, as described above.

DNA extraction and molecular detection of the G143A mutation. A subsample of 161 A. alternata isolates, phenotypically identified as QoI resistant, were arbitrarily selected to confirm the presence of the G143A mutation using polymerase chain reaction restriction fragment length polymorphism (PCR-RFLP) analysis (60). Additionally, 74 QoI-sensitive isolates were also arbitrarily selected to validate the lack of the G143A mutation. Genomic DNA was extracted from 3-day-old mycelia cultured on PDA overlaid with cellophane sheets. Mycelia were transferred into a 2-ml microcentrifuge tube containing a 5-mm-diameter stainless steel bead (Qiagen) and disrupted with a TissueLyser II (Qiagen) twice for $30 \mathrm{~s}$ and an oscillation frequency of $30 \mathrm{~Hz} / \mathrm{s}$. DNA was extracted using the DNeasy Plant Mini kit (Qiagen) according to the manufacturer's instructions. The total DNA concentration was measured using a NanoDrop ND-1000 spectrophotometer (NanoDrop Technologies). The cytochrome $b$ gene of A. alternata isolates was partially amplified using the primers cytb2f $\left(5^{\prime}-\mathrm{CTA}\right.$ TGG ATC TTA CAG AGC AC-3') and DTRcytb2-INTr (5'-GTA TGT AAC CGT CTC CGT C-3'). PCR reactions were performed in a Peltier Thermal cycler (MJ Research Inc.) in a final volume of $25 \mu$ containing 1 unit of HotStart Taq Plus polymerase (Qiagen), $2.5 \mu \mathrm{l}$ of $10 \times$ PCR buffer, $200 \mu \mathrm{M}$ each dNTP, $0.3 \mu \mathrm{M}$ each primer, and 0.5 to $20 \mathrm{ng}$ of fungal DNA template. Cycling parameters were performed as previously described (60). PCR products were visualized with UV light after electrophoresis in $1.2 \%$ agarose gel with $1 \times$ Tris-acetate-EDTA buffer stained with SYBR DNA gel stain (Invitrogen life Technologies).

PCR products were purified using the MiniElute PCR purification kit (Qiagen) following the manufacturer's instructions. Purified PCR $(10 \mu \mathrm{l})$ product was digested with restriction enzyme Fnu4HI (New England Biolabs) at $37^{\circ} \mathrm{C}$ for $1 \mathrm{~h}$, according to the manufacturer's recommendations. Restriction fragments were separated and visualized by electrophoresis in $1.6 \%$ agarose gel.

Statistical analysis. Absorbance values from resazurin reduction tests were plotted against the $\log _{10}$-transformed fungicide concentration, and $\mathrm{EC}_{50}$ values (expressed as micrograms per milliliter) were calculated for each isolate using either sigmoidal or exponential decay functions (60) with SigmaPlot (ver. 11.0; Systat Software Inc.). EC $\mathrm{EC}_{50}$ values were $\log _{10}$-transformed prior to testing for normality using the Shapiro-Wilk test in PROC UNIVARIATE (ver. 9.3; SAS Institute) and graphically analyzed. Probabilistic distributions of baselines were calculated with InfoStat (ver. 2004; InfoStat). To determine whether $\mathrm{EC}_{50}$ values of QoI fungicides from sensitive and resistant isolates were significantly higher than those from baseline isolates, a two-sample $t$ test and a nonparametric Kruskal Wallis test were performed using PROC TTEST (SAS Institute) and InfoStat, respectively. The $\chi^{2}$ tests were performed to examine whether the proportion of QoI-resistant isolates was distributed randomly over cultivars, field disease severity, virulence class, and number of QoI applications per year using PROC FREQ (SAS Institute). Cross-resistance between azoxystrobin and pyraclostrobin was determined by calculating a Pearson correlation coefficient using PROC REG and PROC CORR (SAS Institute).

\section{Results}

Baseline sensitivity to azoxystrobin and pyraclostrobin. The 40 monoconidial A. alternata isolates were log-normally distributed for both azoxystrobin $(W=0.9621, P=0.1969)$ and pyraclostrobin $(W=0.9451, P=0.0516)$. The range of $\mathrm{EC}_{50}$ values for azoxystrobin was 0.012 to $0.356 \mu \mathrm{g} / \mathrm{ml}$, with mean and median $\mathrm{EC}_{50}$ values of 0.135 and $0.098 \mu \mathrm{g} / \mathrm{ml}$, respectively (Table 1; Fig. 1A). Pyraclostrobin had a higher intrinsic activity than azoxystrobin. $\mathrm{EC}_{50}$ values for pyraclostrobin were 0.003 to 0.053 $\mu \mathrm{g} / \mathrm{ml}$, with mean and median $\mathrm{EC}_{50}$ values of 0.023 and 0.020 $\mu \mathrm{g} / \mathrm{ml}$, respectively (Table 1; Fig. 1B). The probability of an isolate from the baseline population sampled showing an $\mathrm{EC}_{50}$ value greater than 5 and $0.5 \mu \mathrm{g} / \mathrm{ml}$, proposed as discriminatory concentrations to differentiate sensitive and resistant isolates for azoxystrobin and pyraclostrobin respectively, was $2.01 \times 10^{-6}$ for azoxystrobin and $8.74 \times 10^{-6}$ for pyraclostrobin. A significant positive correlation $(r=0.8001, P<0.0001)$ was observed between azoxystrobin and pyraclostrobin $\mathrm{EC}_{50}$ values.

A. alternata isolate collection. From 2008 to 2012, 2,653 A. alternata isolates were collected in Florida from 46 commercial citrus orchards encompassing 78 blocks. Of 2,653 isolates, 1,258 were tested for pathogenicity, of which 290 and 165 isolates were from Dancy and Sunburst tangerine, respectively; 21, 315, and 40 were from Lee, Minneola, and Orlando tangelo, respectively; and 427 were from Murcott tangor. More than $92 \%$ of Dancy, Lee, Minneola, and Orlando isolates were pathogenic, whereas, with Murcott and Sunburst, the proportion of pathogenic isolates was 84 and $68 \%$, respectively.

QoI resistance in Florida citrus orchards. Among the 817 field isolates evaluated, $471(57.6 \%)$ were resistant to both azoxystrobin and pyraclostrobin (Table 2). A completely QoI-resistant population was observed in 19 orchards, encompassing 25 blocks; mixed populations of QoI-resistant and -sensitive isolates were observed in 24 orchards (39 blocks); whereas a completely sensitive population was observed in 9 orchards (14 blocks). The frequency of QoI-resistant isolates in orchards with mixed populations varied from 7 to $95 \%$. The presence of QoI-resistant isolates was widespread and very common across tangerine-producing counties in Florida (Fig. 2).

Sensitivity distribution of $A$. alternata isolates to azoxystrobin and pyraclostrobin. The sensitivity distribution of
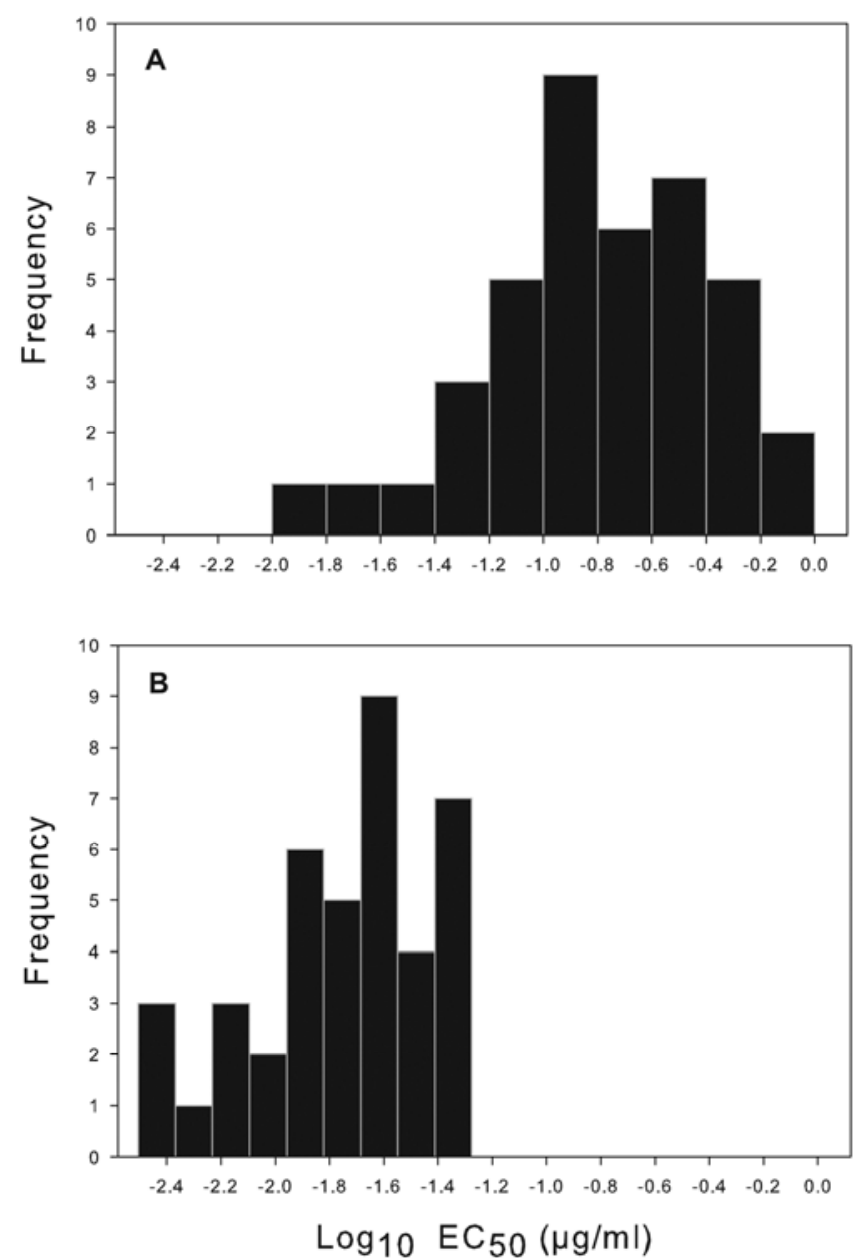

Fig. 1. Baseline sensitivity distribution of Alternaria alternata isolates $(n=40)$ to $A$, azoxystrobin and $\mathbf{B}$, pyraclostrobin, based on effective concentration needed to reduce fungal growth by $50 \%\left(\mathrm{EC}_{50}\right)$ values. 
Table 2. Origin, history of fungicide exposure, and detection of quinone outside inhibitor (QoI) resistance in Alternaria alternata isolates collected in Florida citrus groves from 2008 to 2012

\begin{tabular}{|c|c|c|c|c|c|c|c|c|}
\hline $\begin{array}{l}\text { Isolate } \\
\text { group }\end{array}$ & Location, county & Year & Exposures $^{\mathbf{a}}$ & Host $^{\mathbf{b}}$ & Severity $^{c}$ & Class $^{d}$ & $\begin{array}{l}\text { Number of } \\
\text { isolates tested }\end{array}$ & $\begin{array}{l}\text { Number of } \\
\text { resistant isolates }\end{array}$ \\
\hline 1 & Fort Meade, Polk & 2010 & 1 & Murcott tangor & Low & 1.5 & 14 & 1 \\
\hline \multirow[t]{2}{*}{2} & Haines City, Polk & 2010 & 4 & Minneola tangelo & Low & 2.5 & 16 & 16 \\
\hline & & 2010 & 4 & Murcott tangor & Low & 2 & 14 & 6 \\
\hline 3 & Umatilla, Lake & 2011 & 2 & Minneola tangelo & NA & 3 & 12 & 12 \\
\hline 4 & Tavares, Lake & 2012 & 2 & Minneola tangelo & Moderate & 2 & 10 & 0 \\
\hline \multirow[t]{2}{*}{5} & Fort Myers, Lee & 2012 & 3 & Murcott tangor & Moderate & 2 & 24 & 5 \\
\hline & & 2012 & 3 & Sunburst tangerine & Low & 1 & 2 & 1 \\
\hline \multirow[t]{7}{*}{6} & Avon Park, Highlands & 2011 & 2 & Minneola tangelo & Moderate & 2 & 16 & 13 \\
\hline & Avon Park, Highlands & 2011 & 2 & Murcott tangor & Moderate & 2 & 27 & 25 \\
\hline & Babson Park, Polk & 2011 & 2 & Murcott tangor & Low & 2 & 15 & 14 \\
\hline & Fort Meade, Polk & 2011 & 2 & Murcott tangor & Moderate & 2 & 16 & 14 \\
\hline & Frostproof, Polk & 2009 & 2 & Murcott tangor & High & 2.5 & 10 & 5 \\
\hline & Frostproof, Polk & 2011 & 2 & Minneola tangelo & Moderate & 2 & 16 & 6 \\
\hline & Frostproof, Polk & 2011 & 2 & Murcott tangor & Low & 2 & 8 & 7 \\
\hline 7 & Crooked Lake, Polk & 2010 & 1 & Murcott tangor & Low & 2 & 14 & 1 \\
\hline 8 & Bartow, Polk & 2012 & 1 & Murcott tangor & Moderate & 2 & 11 & 8 \\
\hline 9 & Davenport, Polk & 2010 & 2 & Murcott tangor & High & 3 & 15 & 2 \\
\hline 10 & Bartow, Polk & 2012 & 1 & Sunburst tangerine & Low & 2 & 12 & 0 \\
\hline 11 & Winter Haven, Polk & 2010 & 1 & Dancy mandarin & High & 3 & 15 & 8 \\
\hline \multirow[t]{2}{*}{12} & Clermont, Lake & 2012 & 2 & Murcott tangor & High & 2 & 12 & 6 \\
\hline & & 2012 & 2 & Sunburst tangerine & Low & 2 & 11 & 10 \\
\hline 13 & Felda, Hendry & 2012 & 2 & Murcott tangor & Moderate & 3 & 12 & 6 \\
\hline 14 & Dundee, Polk & 2009 & 2 & Murcott tangor & High & 2 & 23 & 23 \\
\hline 15 & Lake Wales, Polk & 2010 & 2 & Minneola tangelo & $\mathrm{NA}$ & 3 & 13 & 13 \\
\hline 16 & Fort Pierce, St. Lucie & 2012 & 2 & Murcott tangor & Low & 3 & 2 & 0 \\
\hline \multirow[t]{2}{*}{17} & Fort Meade, Polk & 2012 & 4 & Murcott tangor & Moderate & 2 & 9 & 9 \\
\hline & & 2012 & 1 & Sunburst tangerine & Moderate & 2 & 10 & 4 \\
\hline 18 & Fort Pierce, St. Lucie & 2011 & 4 & Minneola tangelo & Moderate & 2 & 10 & 10 \\
\hline 19 & Fort Pierce, St. Lucie & 2010 & NA & Minneola tangelo & NA & 3 & 14 & 14 \\
\hline 20 & Immokalee, Collier & 2012 & $>1$ & Murcott tangor & Low & 2 & 11 & 2 \\
\hline 21 & Vero Beach, Indian River & 2011 & 4 & Minneola tangelo & High & 3 & 30 & 30 \\
\hline 22 & Vero Beach, Indian River & 2011 & NA & Sunburst tangerine & Low & 2 & 3 & 2 \\
\hline 23 & Venus, Highlands & 2012 & 2 & Murcott tangor & Low & 2.5 & 12 & 3 \\
\hline 24 & Immokalee, Collier & 2012 & 2 & Murcott tangor & Moderate & 3 & 12 & 2 \\
\hline 25 & Lake Wales, Polk & 2010 & 2 & Murcott tangor & Moderate & 2 & 15 & 5 \\
\hline 26 & Zolfo Springs, Hardee & 2011 & 2 & Minneola tangelo & High & 2 & 10 & 10 \\
\hline 27 & St. Cloud, Osceola & 2010 & 1 & Sunburst tangerine & Moderate & 1 & 9 & 5 \\
\hline 28 & Polk City, Polk & 2012 & $>3$ & Sunburst tangerine & Moderate & 2 & 12 & 8 \\
\hline \multirow[t]{2}{*}{29} & Clermont, Lake & 2012 & 1 & Orlando tangelo & High & 1 & 11 & 0 \\
\hline & & 2012 & 1 & Sunburst tangerine & Moderate & 1 & 11 & 3 \\
\hline 30 & Oviedo, Seminole & 2009 & $>4$ & Minneola tangelo & High & 3 & 2 & 2 \\
\hline \multirow[t]{2}{*}{31} & Fort Meade, Polk & 2010 & 0 & Murcott tangor & Moderate & 1 & 11 & 0 \\
\hline & & 2010 & 0 & Sunburst tangerine & Moderate & 2 & 10 & 0 \\
\hline 32 & Lake Wales, Polk & 2011 & 3 & Minneola tangelo & Moderate & 2 & 11 & 11 \\
\hline 33 & Nokomis, Sarasota & 2011 & 2 & Minneola tangelo & Moderate & 2 & 9 & 9 \\
\hline 34 & Vero Beach, Indian River & 2011 & 4 & Minneola tangelo & Low & 2 & 10 & 10 \\
\hline 35 & Bartow, Polk & 2012 & 2 & Murcott tangor & Low & 2 & 1 & 1 \\
\hline \multirow[t]{2}{*}{36} & Fort Pierce, St. Lucie & 2011 & 4 & Minneola tangelo & High & 2 & 23 & 23 \\
\hline & & 2011 & 4 & Murcott tangor & Low & 1 & 1 & 1 \\
\hline \multirow[t]{2}{*}{37} & Eustis, Lake & 2012 & 2 & Minneola tangelo & High & 2 & 10 & 0 \\
\hline & & 2012 & 2 & Orlando tangelo & Moderate & 2 & 9 & 0 \\
\hline 38 & Immokalee, Collier & 2012 & 2 & Sunburst tangerine & Moderate & 2 & 20 & 17 \\
\hline \multirow[t]{2}{*}{39} & Haines City, Polk & 2010 & $>3$ & Murcott tangor & Moderate & 3 & 16 & 14 \\
\hline & & 2010 & $>3$ & Orlando tangelo & Low & 2 & 16 & 12 \\
\hline \multirow[t]{2}{*}{40} & Winter Haven, Polk & 2008 & $>6$ & Dancy mandarin & High & 3 & 20 & 19 \\
\hline & & 2010 & $>5$ & Dancy mandarin & High & 2 & 16 & 12 \\
\hline 41 & Vero Beach, Indian River & 2011 & NA & Minneola tangelo & Moderate & 3 & 10 & 10 \\
\hline 42 & Haines City, Polk & 2010 & 2 & Lee citrus hybrid & High & 2 & 9 & 0 \\
\hline & & 2010 & 2 & Minneola tangelo & High & 2 & 10 & 0 \\
\hline & & 2010 & 2 & Murcott tangor & High & 2 & 9 & 0 \\
\hline 43 & Wauchula, Hardee & 2011 & 1 & Murcott tangor & NA & 2 & 12 & 12 \\
\hline 44 & Mt. Dora, Lake & 2012 & NA & Minneola tangelo & High & 2 & 11 & 0 \\
\hline & & 2012 & NA & Murcott tangor & Low & 2 & 10 & 0 \\
\hline 45 & Grand Island, Lake & 2012 & 2 & Lee citrus hybrid & Moderate & 3 & 12 & 1 \\
\hline & & 2012 & 2 & Murcott tangor & Moderate & 3 & 12 & 3 \\
\hline & & 2012 & 2 & Sunburst tangerine & Low & 2.5 & 12 & 0 \\
\hline 46 & Oviedo, Seminole & 2009 & $>4$ & Minneola tangelo & High & 3 & 6 & 5 \\
\hline
\end{tabular}

a $\mathrm{QoI}$ exposures per year; $\mathrm{NA}=$ not available.

${ }^{\mathrm{b}}$ Tangor $=$ Citrus reticulata $\times$ C. sinensis, tangelo $=$ C. reticulata $\times$ C. paradisi, tangerine or mandarin $=$ C. reticulata, and citrus hybrid $=$ C. reticulata $\times$ tangelo.

${ }^{\mathrm{c}}$ Field severity was evaluated based on symptom distribution, where Low $=$ small scattered lesions on old leaves, Moderate $=$ mild coalescing lesions on young leaves and fruit, and High $=$ abundant lesions in young and old leaves as well as fruit; NA = not available.

${ }^{\mathrm{d}}$ Median virulence class. Virulence tested by spray inoculation of detached tangerine leaves and rated 48 to $72 \mathrm{~h}$ after incubation, where $1=<25 \%, 2=25$ to $50 \%$, and $3=>50 \%$ leaf area.

${ }^{\mathrm{e}}$ Resistant isolates grew on complete medium in resazurin-based microtiter assay amended with azoxystrobin at $>5 \mu \mathrm{g} / \mathrm{ml}$ or pyraclostrobin at $>0.5 \mu \mathrm{g} / \mathrm{ml}$. Sensitive isolates did not grow at those fungicide concentrations. 
A. alternata isolates showed a clear division between QoI-sensitive and -resistant populations (Fig. 3). The $\mathrm{EC}_{50}$ values of the sensitive populations for azoxystrobin and pyraclostrobin were 0.012 to 0.836 and 0.002 to $0.116 \mu \mathrm{g} / \mathrm{ml}$, respectively, resulting in mean $\mathrm{EC}_{50}$ values of 0.139 and $0.020 \mu \mathrm{g} / \mathrm{ml}$, respectively. The mean $\mathrm{EC}_{50}$ values of sensitive populations for both azoxystrobin and pyraclostrobin was not significantly different $(t=-0.51, P=0.6095$ and $t=1.79, P=0.0739$, respectively) than the baseline populations. $\mathrm{EC}_{50}$ values of the resistant populations were 6.626 to $>10$ $\mu \mathrm{g} / \mathrm{ml}$ for azoxystrobin and 1.130 to $>10 \mu \mathrm{g} / \mathrm{ml}$ for pyraclostrobin, with a median $\mathrm{EC}_{50}$ value of $>10$ and $5.507 \mu \mathrm{g} / \mathrm{ml}$ for azoxystrobin and pyraclostrobin, respectively. On the other hand, the median $\mathrm{EC}_{50}$ values of resistant populations was significantly higher $(H=$ $110.39, P<0.0001$ for azoxystrobin and pyraclostrobin) than the baseline populations. RF, expressed as the ratio of the $\mathrm{EC}_{50}$ value of a pyraclostrobin-resistant isolate to the mean $\mathrm{EC}_{50}$ for pyraclostrobin baseline sensitive isolates, was unimodally distributed (Supplementary Figure S1). The RF was 50 to $>439$, with a median of 241.5.

Cross-resistance to QoI fungicides. A $\chi^{2}$ analysis of 817 QoIresistant and -sensitive isolates $(P=0.999)$ and Pearson correlation analysis of 346 QoI-sensitive isolates showed that $\mathrm{EC}_{50}$ values for azoxystrobin and pyraclostrobin were highly correlated $(r=$ 0.866, $P<0.0001$ ), suggesting a high level of cross-resistance between the two QoI fungicides (Fig. 4).

QoI resistance associated with citrus hosts and orchard factors. The frequency of resistant isolates was significantly different $\left(\chi^{2}=97.534, P<0.0001\right)$ among cultivars (Fig. 5). Lee showed the lowest proportion of resistant isolates. The highest proportion of resistant isolates was found in Minneola and Dancy and they did not significantly differ $\left(\chi^{2}=0.051, P=0.822\right)$. Moreover, the pro- portion of resistance isolates was not significantly different $\left(\chi^{2}=\right.$ 4.33, $P=0.115$ ) among Murcott, Orlando, and Sunburst (Fig. 5).

The proportion of resistant isolates was not significantly different (Table 3) among the field disease severity categories (low, moderate, and high) evaluated. In orchards with low disease severity, $47 \%$ of the isolates were resistant. In orchards with moderate disease severity, the proportion of resistant isolates was $55 \%$ whereas, in orchards with high disease severity, $60 \%$ of the isolates tested were resistant (Table 3).

No significant differences in the proportion of resistant isolates were observed when A. alternata virulence class was examined (Table 3). Nevertheless, in Minneola, the proportion of resistant isolates was significantly different $\left(\chi^{2}=24.554, P<0.0001\right)$ among virulence classes. Almost $90 \%$ of resistant isolates from Minneola were highly virulent whereas, in other cultivars, the proportion of resistance was evenly distributed (data not shown).

A positive correlation was found between number of QoI applications and frequency of resistance $(r=0.938 ; P=0.0056)$. Resistant isolates were found more frequently in orchards with more than four QoI applications per year (Table 3). On the other hand, in orchards with no QoI exposure, no resistant isolates were detected. In general, the proportion of resistant isolates increased with number of QoI applications per year.

Detection of the G143A mutation. A PCR-RFLP analyses was used to differentiate between isolates carrying the wild-type GGT codon (glycine) at amino acid 143 and those with the mutant allele containing a GCT (alanine) codon in the A. alternata population. Two distinct cytochrome $b$ gene structures were identified based on the presence of one or two introns (60). A 377-bp fragment was amplified in isolates carrying one intron, designated as profile I, whereas a 1,564-bp fragment was amplified in isolates carrying

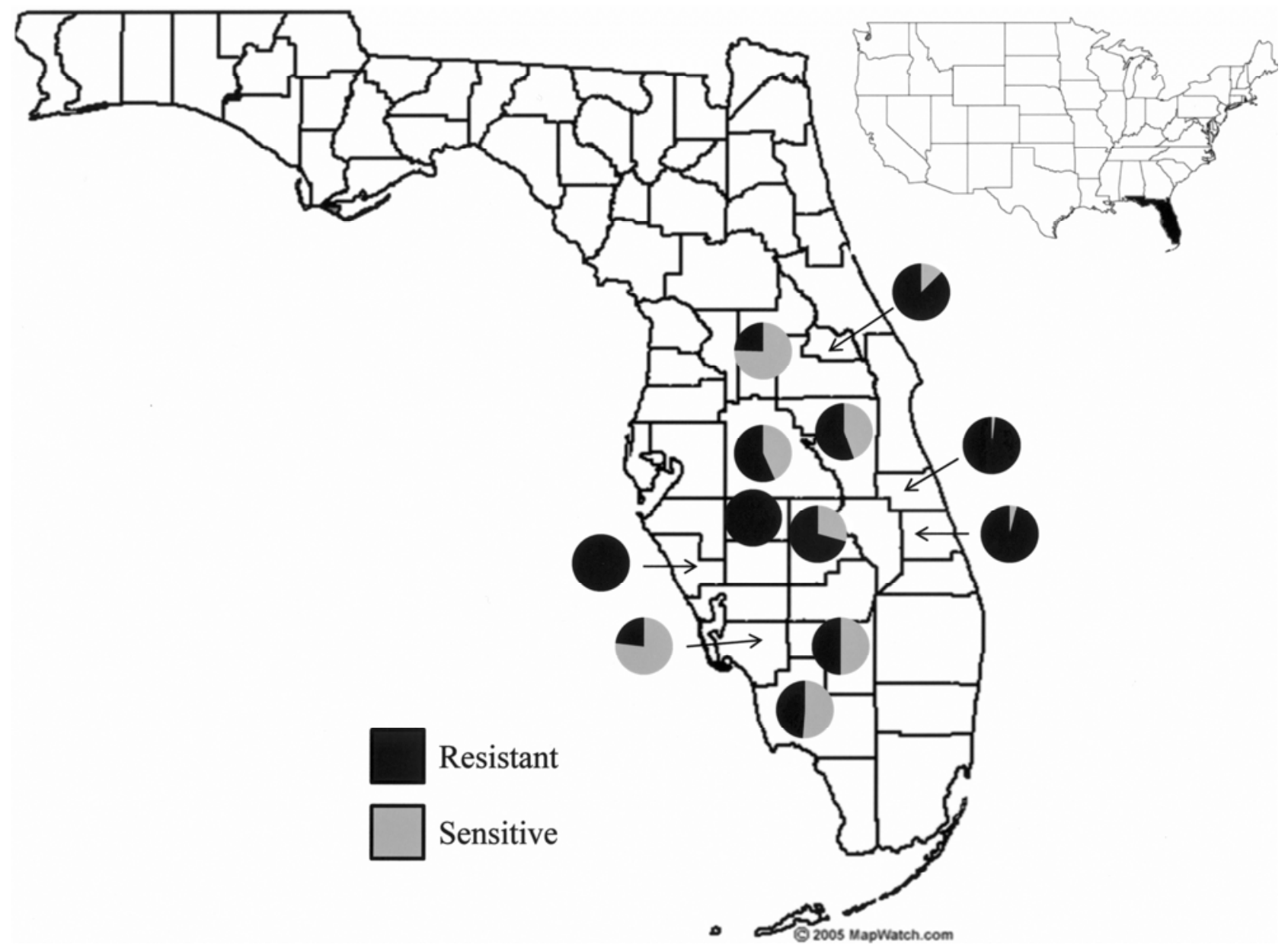

Fig. 2. Geographic distribution of quinone outside inhibitor-sensitive and -resistant Alternaria alternata isolates collected in 46 commercial citrus orchards encompassing 78 blocks from 2008 to 2012. 
two introns, designated as profile II. The restriction enzyme Fnu4HI generated two fragments in isolates carrying the mutant allele G143A. The length of the fragments was $123 \mathrm{p}$ and $254 \mathrm{bp}$ for profile I isolates and 254 and $1,310 \mathrm{bp}$ for profile II isolates (Fig. 6). The fragments of 377 and 1,564 bp remained undigested in wild-type isolates profile I and profile II, respectively (Fig. 6B). The amino acid substitution G143A was present in all 161 QoIresistant isolates tested and absent in all 74 sensitive isolates tested.

Between sensitive and resistant isolates, the proportion of isolates carrying the cytochrome $b$ profile I or profile II was significantly different $\left(\chi^{2}=118.824, P<0.0001\right)$. The proportion of profile II isolates was $54 \%$ in resistant isolates and only $1 \%$ in sensitive isolates (Fig. 7). The proportion of profile I isolates among the populations tested was less skewed. In all, $31 \%$ of sensitive isolates and $14 \%$ of resistant isolates were profile I (Fig. 7).

\section{Discussion}

QoIs have been used for more than a decade in Florida for ABS control (16). Due to their effectiveness against A. alternata and good weathering properties, growers adopted them very quickly. Despite their excellent characteristics, resistance to QoI fungicides has been detected in many plant pathogens within a few years of their introduction to a cropping system (22). QoI resistance in Alternaria populations has been identified in vegetables as well as fruit and nuts such as pistachio (40), pear (27), apple (38), and potato (44). In 2008, QoI resistance of tangerine-infecting A. alternata isolates was detected in Polk County, FL (43), making ABS management considerably more difficult and costly. Tangerine production in Florida is mainly for the fresh-fruit market; therefore, the production of disease-free fruit is paramount and is heav-
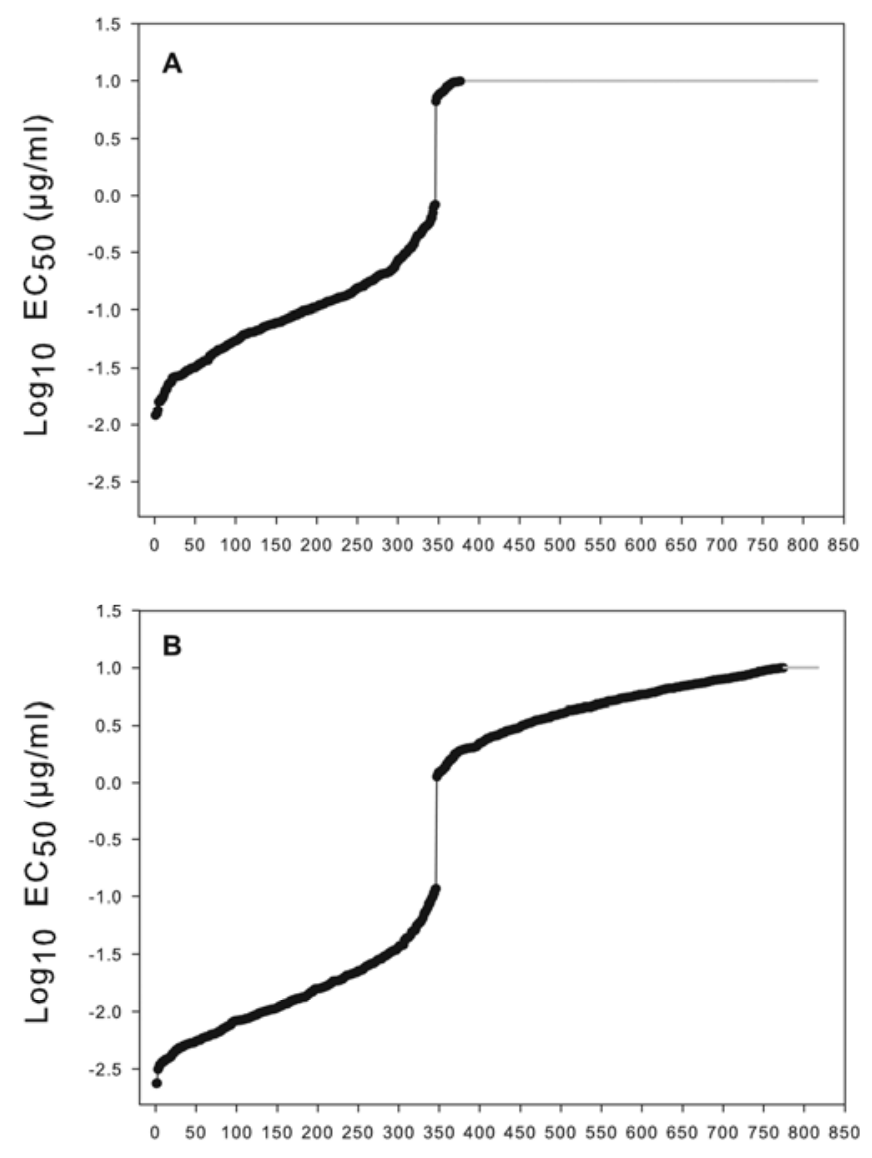

Isolate number

Fig. 3. Sensitivity distribution of Alternaria alternata isolates $(n=817)$ collected in Florida citrus orchards from 2008 to 2012 to A, azoxystrobin and B, pyraclostrobin, based on effective concentration needed to reduce fungal growth by $50 \%\left(\mathrm{EC}_{50}\right)$ values. Black circles denote $\mathrm{EC}_{50}$ values for individual isolates; while small gray dots denote resistant isolates with $\mathrm{EC}_{50}$ values $>10 \mu \mathrm{g} / \mathrm{ml}$. ily reliant on fungicides, thus increasing the risk for resistance development. This is particularly true for the site-specific fungicides such as the QoIs. Our study represents the first report of the statewide QoI sensitivity distribution in the tangerine-infecting $A$. alternata population of Florida using both phenotypic and molecular approaches.

In the current study, the baseline distribution of A. alternata to azoxystrobin and pyraclostrobin was established using never-exposed isolates collected before the introduction of QoIs to citrus. In fungicide resistance monitoring programs, the establishment of baseline sensitivity is of great importance. It can be used to monitor for changes in the sensitivity profiles of target populations exposed to the tested modes of action over time. Comparisons of new populations to the baseline can give evidence of increasing frequency of resistance in the population that could lead to future control failure (50). The baseline distribution of azoxystrobin and pyraclostrobin was log-normally distributed within a relatively narrow range. The mean $\mathrm{EC}_{50}$ value for azoxystrobin obtained in our baseline study $(0.135 \mu \mathrm{g} / \mathrm{ml})$ was a little higher than the mean $\mathrm{EC}_{50}$ value observed in other wild-type Alternaria spp. For 14 pistachio-infecting $A$. alternata isolates, the mean $\mathrm{EC}_{50}$ value was $0.023 \mu \mathrm{g} / \mathrm{ml}$ (40) whereas, in $32 \mathrm{~A}$. solani isolates from potato, the

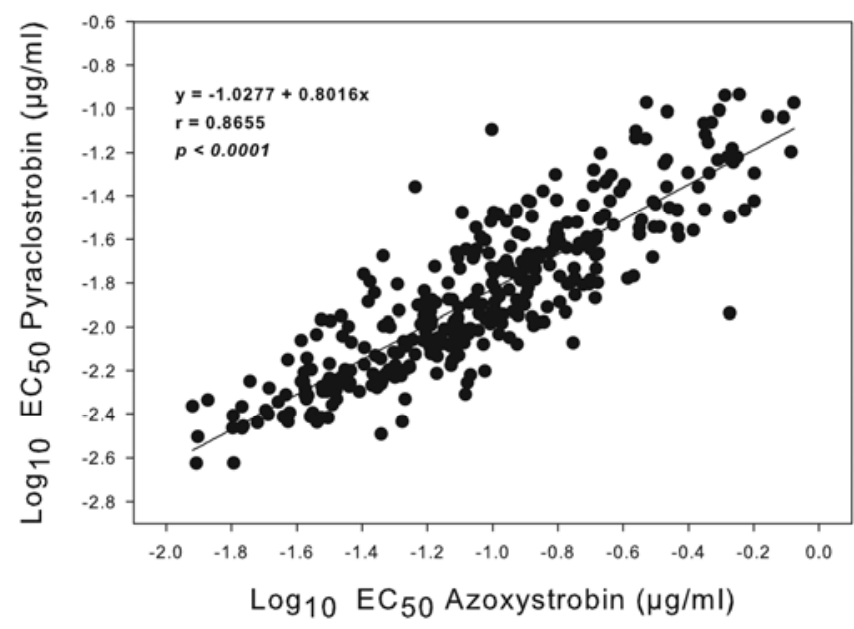

Fig. 4. Correlation of effective concentration needed to reduce fungal growth by $50 \%\left(\mathrm{EC}_{50}\right)$ values of azoxystrobin and pyraclostrobin in quinone outside inhibitorsensitive Alternaria alternata isolates $(n=346)$.

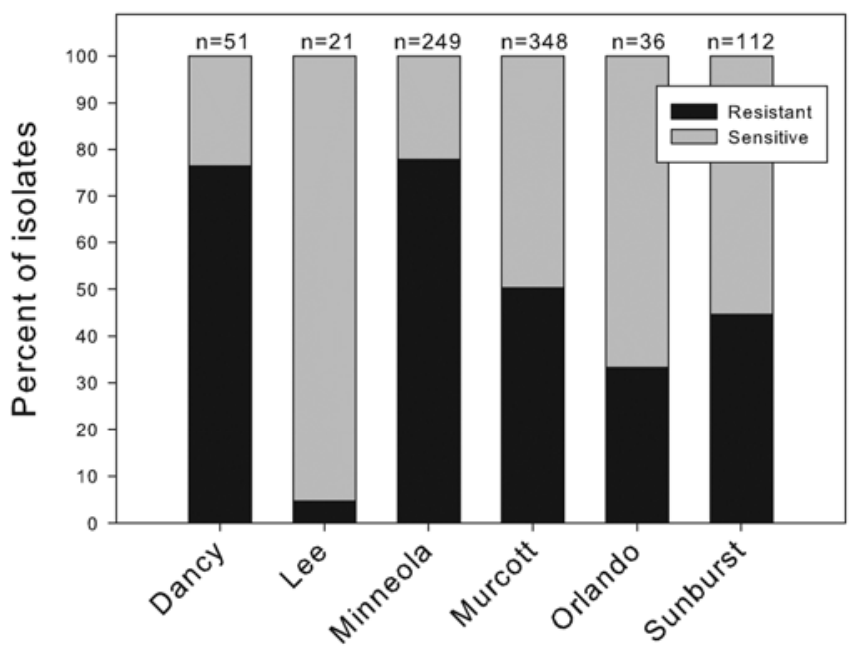

Fig. 5. Distribution of sensitive $(n=346)$ and resistant $(n=471)$ Alternaria alternata isolates to azoxystrobin and pyraclostrobin collected during 2008 to 2012 from Florida tangerine and tangerine hybrids orchards. Isolates were considered resistant when they grew on complete medium in resazurin-based microtiter assay amended with fungicide at concentrations $>5$ or $>0.5 \mu \mathrm{g} / \mathrm{ml}$ for azoxystrobin and pyraclostrobin, respectively. 
mean $\mathrm{EC}_{50}$ value was $0.038 \mu \mathrm{g} / \mathrm{ml}(44,49)$. Some differences are expected because two different methods were used to determine the $\mathrm{EC}_{50}$ values (resazurin-based microtiter test versus spore germination assay) and because of the intrinsic interspecies variation in fungicide sensitivity. Our baseline result for azoxystrobin did not match the study done by Mondal et al. (42), in which the mean $\mathrm{EC}_{50}$ value from five wild-type A. alternata citrus isolates was $>100 \mu \mathrm{g} / \mathrm{ml}$. However, this is likely because Mondal et al. (42) determined the $\mathrm{EC}_{50}$ with a mycelial growth inhibition test and it appears that $A$. alternata mycelium is insensitive to azoxystrobin but not to pyraclostrobin.

The sensitivity distribution of the A. alternata populations to azoxystrobin and pyraclostrobin from the 2008 to 2012 surveys shows two clear populations of QoI-sensitive and -resistant isolates. This type of distribution suggests a disruptive, monogenic resistance, as expected for site-specific fungicides like QoIs (11). Our results revealed that $A$. alternata isolates continued to be more sensitive to pyraclostrobin than azoxystrobin, consistent with previous studies on several pathogens from citrus and vegetable crops $(2,10,42,48)$. A positive correlation was found between azoxystrobin and pyraclostrobin, demonstrating cross-resistance between these two QoI fungicides, as previously described in other systems $(13,19,31,35,52)$. Based on the $\mathrm{EC}_{50}$ values of sensitive and resistant populations, we established discriminatory concentrations for both QoI fungicides for rapid identification of resistant isolates. We suggest the discriminatory concentrations of 5 and 0.5 $\mu \mathrm{g} / \mathrm{ml}$ for azoxystrobin and pyraclostrobin, respectively, which approximately corresponds to the lowest $\mathrm{EC}_{50}$ values of resistant isolates. The mean resazurin reduction of the sensitive population exposed at concentrations of 5 or $0.5 \mu \mathrm{g} / \mathrm{ml}$ for azoxystrobin and pyraclostrobin, respectively, decreased to less than $25 \%$ while the resistant population, exposed at the same fungicide concentrations, maintained the same levels of resazurin reduction as non-QoIamended media (higher than 90\%). The $\mathrm{EC}_{50}$ values for the pyraclostrobin-resistant population had a left-skewed distribution, where $88 \%$ of resistant isolates had an RF greater than 100 and all carried the G143A mutation in the cytochrome $b$ gene.

Our study shows that $A$. alternata resistance to azoxystrobin and pyraclostrobin is widespread in commercial citrus orchards in Florida; QoI-resistant isolates were found in 64 of 78 blocks sampled. The proportion of resistant isolates was greater than $25 \%$ in $73 \%$ of the blocks sampled, indicating that QoI resistance is likely to continue to increase with continued selection. Similarly, selection for QoI resistance was observed in almond- and pistachio-infecting
A. alternata, where 36 of 41 orchards sampled in 2005 showed more than $90 \%$ azoxystrobin-resistant isolates (39). The resistant population was most prevalent in the Indian River region on the east coast of Florida. This region comprises $12 \%$ of the total tangerine production area, consisting mainly of Minneola tangelo and Murcott tangor. Minneola commands a high fresh-fruit market price but, of the commercial tangerine cultivars grown in this area, it is also the most susceptible to ABS $(53,58)$. To obtain good fruit quality and premium prices, more fungicide applications are often needed to manage disease on this cultivar compared with less-susceptible, lower-value cultivars such as the Sunburst tangerine. In the Indian River region, growers have used QoI fungicides more than three times per year, suggesting that the QoI-resistant population has been selected over time, as previously described in pistachio-infecting A. alternata (40). In contrast, the central region (Polk, Lake, Highlands, and Osceola Counties) is the largest tangerine-production area, comprising $48 \%$ of the total tangerine production area, and the cultivar diversity is higher compared with other regions; therefore, fewer QoI applications per year occur. In Florida, disease management programs and, hence, QoI selection pressure has varied according to the level of cultivar susceptibility to ABS. Sunburst tangerine is one of the least susceptible cultivars; thus, growers used fewer fungicide applications for ABS control on Sunburst than on Minneola tangelo. In fact, four of the seven Sunburst producers in the central region used QoI fungicides no more than once per year. Despite the low numbers of applications on Sunburst, some groves still showed a considerable proportion of resistant isolates ( $>30 \%$ ), suggesting that only a few QoI applications are needed to start the selection of a resistant population.

Susceptibility to ABS is a dominant trait from the Dancy mandarin parent while resistance to ABS is controlled by a recessive allele $(15,26)$. Many of the grapefruit $\times$ tangerine and tangerine $\times$ sweet orange hybrids are the result of crosses with Dancy tangerine and, therefore, susceptible to ABS. We observed higher disease intensity in the most susceptible cultivars, Minneola and Dancy, compared with the less susceptible cultivars, Murcott or Sunburst. In fact, $97 \%$ of isolates recovered from brown spot lesions on Minneola were pathogenic, whereas only $68 \%$ of Sunburst isolates were pathogenic, consistent with previous reports (45). Cultivar susceptibility to ABS was closely associated with QoI-resistance frequency and may be contributing to decreased efficacy of fungicide programs in some citrus orchards. The most susceptible cultivars, Minneola and Dancy, had a higher proportion of QoI-resistant isolates than the other cultivars. At least two factors could contrib-

Table 3. A $\chi^{2}$ analysis of quinone outside inhibitor (QoI)-resistant isolates of Alternaria alternata collected in Florida from 2008 to 2012 according to field severity, virulence class, and number of QoI applications per year

\begin{tabular}{|c|c|c|c|c|c|}
\hline Response variable, levels & Number of isolates tested & Number of resistant isolates ${ }^{a}$ & $\chi^{2}$ & $\mathbf{d f}^{\mathbf{b}}$ & $P$ value \\
\hline \multicolumn{6}{|l|}{ Field severity ${ }^{c}$} \\
\hline Low & 184 & 87 & 2.021 & 2 & 0.3641 \\
\hline Moderate & 340 & 188 & $\ldots$ & $\ldots$ & $\ldots$ \\
\hline High & 242 & 145 & $\ldots$ & $\ldots$ & $\ldots$ \\
\hline \multicolumn{6}{|l|}{ Virulence class ${ }^{\mathrm{d}}$} \\
\hline 1 & 163 & 81 & 1.849 & 2 & 0.3970 \\
\hline 2 & 341 & 192 & $\ldots$ & $\ldots$ & $\ldots$ \\
\hline 3 & 300 & 186 & $\ldots$ & $\ldots$ & $\ldots$ \\
\hline \multicolumn{6}{|l|}{ QoI exposures ${ }^{\mathrm{e}}$} \\
\hline 0 & 21 & 0 & 38.225 & 5 & $<0.0001$ \\
\hline 1 & 119 & 42 & $\ldots$ & $\ldots$ & $\ldots$ \\
\hline 2 & 391 & 209 & $\ldots$ & $\ldots$ & $\ldots$ \\
\hline 3 & 37 & 17 & $\ldots$ & $\ldots$ & $\ldots$ \\
\hline 4 & 157 & 139 & $\ldots$ & $\ldots$ & $\ldots$ \\
\hline$>5$ & 44 & 38 & $\ldots$ & $\ldots$ & $\ldots$ \\
\hline
\end{tabular}

${ }^{\text {a }}$ Resistant isolates grew on complete medium in resazurin-based microtiter assay amended with azoxystrobin at $>5 \mu \mathrm{g} / \mathrm{ml}$ or pyraclostrobin at $>0.5 \mu \mathrm{g} / \mathrm{ml}$. Sensitive isolates did not grow at those fungicide concentrations.

${ }^{\mathrm{b}}$ Degrees of freedom.

${ }^{\mathrm{c}}$ Field severity was evaluated based on symptom distribution, where Low $=$ small scattered lesions on old leaves, moderate $=$ mild coalescing lesions on young leaves and fruit, and high $=$ abundant lesions in young and old leaves as well as fruit.

d Virulence tested by spray inoculation of detached tangerine leaves and rated 48 to $72 \mathrm{~h}$ after incubation, where $1=<25 \%, 2=25$ to $50 \%$, and $3=>50 \%$ leaf area.

${ }^{\mathrm{e}}$ Number of applications per year. 
ute to this finding: first, the abundant sporulation produced on Minneola leaf litter as well as infected leaves still in the canopy leading to increase the inoculum density and disease pressure (59); and, second, the selection pressure on QoI-resistant populations. Growers tend to apply fungicides more frequently when disease pressure is high, putting greater selection pressure on the pathogen population which, over subsequent generations, can lead to higher frequencies of resistance. Later, control failure was observed as a result of the dominance of resistant isolates in the population. Growers observed QoI-control failure when the proportion of resistance in a population was greater than $65 \%$. On average, more than three QoI applications per year were made in Dancy and Minneola orchards while fewer than two were used in the less susceptible cultivars Murcott, Sunburst, Orlando, and Lee. Consequently, QoI selection pressure was higher in the most susceptible cultivars, increasing the frequency of resistant populations over time.

Regardless of cultivar, QoI resistance was not related to the disease severity levels observed in the field. This result implies that QoI resistance in the A. alternata population did not impose a negative effect on pathogenic fitness over time; thus, resistant isolates are able to compete under similar conditions with wild-type isolates. Previous studies indicated no fitness effects for QoI-resistant isolates of Magnaporthe grisea (3), Plasmopara viticola (14), Erysiphe graminis f. sp. tritici (13), or A. alternata (30), among others, and they successfully competed with the sensitive isolates for the same ecological niche. No relationship was observed between QoI exposures per year and field disease severity categories. Nevertheless, the greatest proportion of resistant isolates $(60 \%)$ was obtained from orchards with high disease severity, which implies that resistant isolates were selected and a resistant population built up over time. Likewise, our results showed a lack of relationship between resistant isolates and virulence. Peever et al. (47) found that virulence was similar in different citrus cultivars inoculated with Nova and grapefruit isolates. Disease severity and host specificity of $A$. alternata isolates depend on the production of the host-specific ACT toxin $(32,46)$, controlled by a gene cluster

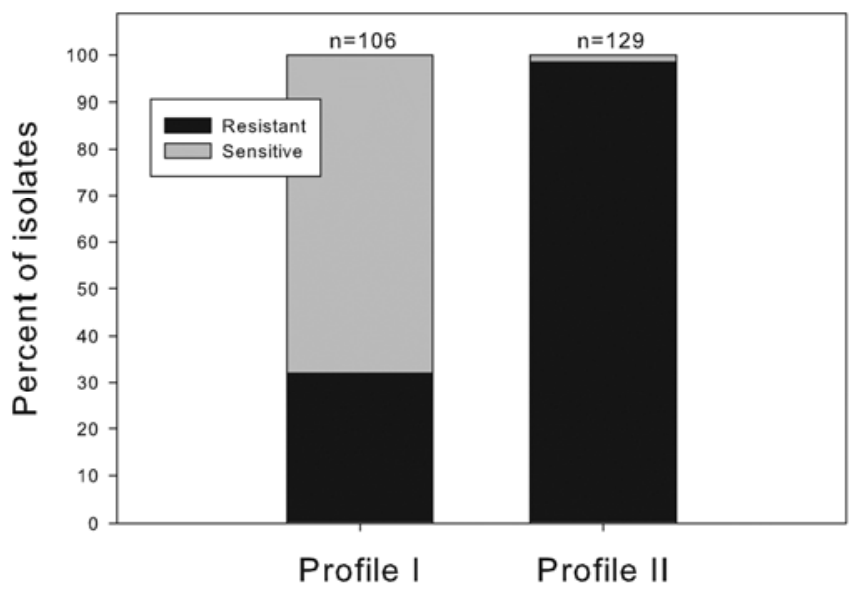

Fig. 7. Frequency distribution of Alternaria alternata isolates sensitive $(n=74)$ and resistant $(n=161)$ to azoxystrobin and pyraclostrobin according to cytochrome $b$ profiles. Profile I isolates had one intron at amino acid F164. Profile II isolates had two introns at amino acid positions A126 and F164. Isolates were considered resistant when they grew on complete medium in resazurin-based microtiter assay amended with fungicide at concentrations $>5$ or $>0.5 \mu \mathrm{g} / \mathrm{ml}$ for azoxystrobin and pyraclostrobin, respectively, and showed the G143A point mutation in the cytochrome $b$ gene.

$\mathbf{A}$

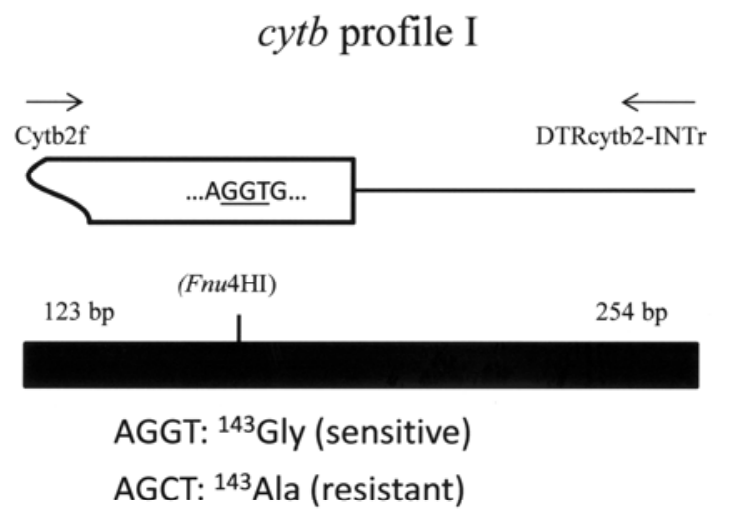

$\mathbf{B}$
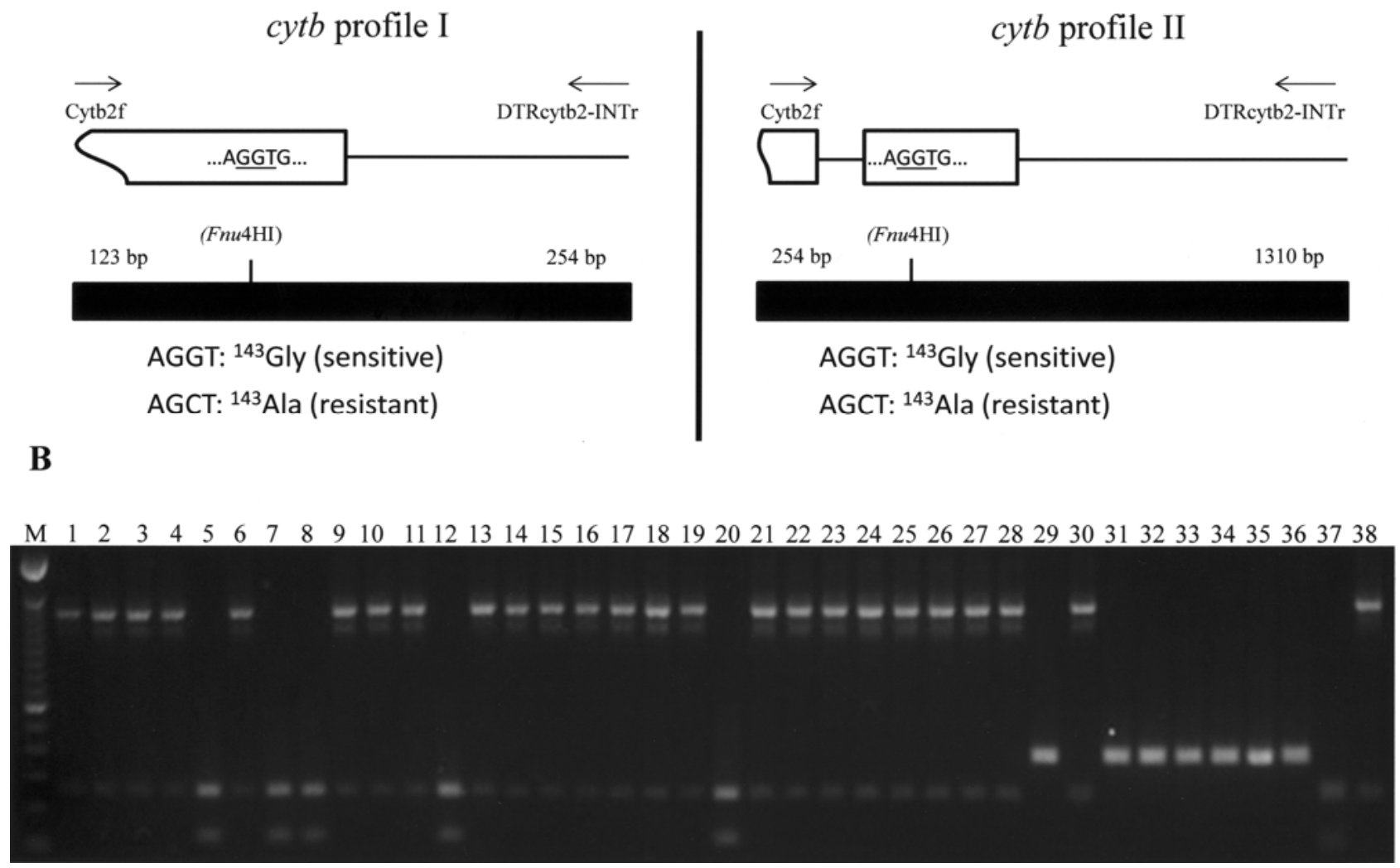

Fig. 6. Restriction-fragment-length-polymorphism analysis of the partial structure of the cytochrome $b$ gene from Alternaria alternata isolates that are either quinone outside inhibitor sensitive or resistant. A, Restriction enzyme Fnu4HI produced two fragments of 123 and 254 bp in resistant isolates (G143A) carrying the cytb profile I whereas, in isolates carrying the cytb profile II, the fragments obtained were of 254 and 1,310 bp. Boxes indicate exons and lines indicate introns. Lengths of exons and introns are not to scale. B, Detection of the G143A mutation with the restriction enzyme Fnu4HI, followed by electrophoresis on $1.6 \%$ agarose gels. Lane M = 100-bp DNA ladder (Invitrogen Life Technologies); lanes 1, 2, 3, 4, 6, 9, 10, 11, 13, 14, 15, 16, 17, 18, 19, 21, 22, 23, 24, 25, 26, 27, 28, 30, and 38 denote resistant isolates carrying the cytb profile II; lanes $5,7,8,12,20$, and 37 denote resistant isolates carrying the cytb profile I; and lanes $29,31,32,33,34,35$, and 36 denote sensitive isolates carrying the cytb profile I. 
involved in the biosynthesis of the toxin (1). Therefore, QoI resistance and virulence are two unrelated mechanisms present in $A$. alternata populations and not necessarily expected to be related to each other.

Only the amino acid substitution of glycine for alanine at codon 143 (G143A) in the cytochrome $b$ was found in the QoI-resistant population. This mutation has been identified in many plant pathogens (22) and confers a high level of resistance (RF higher than 100). The G143A mutation is related to control failure of QoI fungicides (20), such as observed for A. alternata in pistachio (40), $V$. inaequalis in apple (37), E. necator in grape (41), Cercospora beticola in sugar beet (9), Botrytis cinerea in multiple crops $(17,29,36)$, and others. Overall, the G143A mutation was observed in isolates with $\mathrm{EC}_{50}$ values greater than $6 \mu \mathrm{g} / \mathrm{ml}$ for azoxystrobin and greater than $1 \mu \mathrm{g} / \mathrm{ml}$ for pyraclostrobin, which corresponded to an RF greater than 50. The RF lower than 100 observed in $12 \%$ of resistant isolates could be attributed to the method used to determine the $\mathrm{EC}_{50}$ value. Because the resazurin-based microtiter assay is a very sensitive test, the resazurin reduction measurement could be affected by the conidial germination rate of individual isolates, giving a lower $\mathrm{EC}_{50}$ value (60). In fact, the rate of resazurin reduction of some of the resistant isolates with an RF below 100 was lower than $62 \%$, compared with the normal range (between 85 and $95 \%$ ) observed in the majority of all isolates. A lower conidial germination rate could cause the underestimation of the overall dye reduction produced by a specific isolate, decreasing the $\mathrm{EC}_{50}$ value.

Two A. alternata genotypes, profile I and profile II, were evenly distributed in Florida. The genotype designation was based on the presence of one or two introns in the amino acid region of 103 to 268 in the cytochrome $b$ gene (60). Profile I isolates had only one intron at amino acid position 164 (F164). Profile II isolates had two introns, the first one at amino acid position 126 (A126) and the second one at position F164 (60). The cytochrome $b$ gene structures of A. alternata from sunflower and A. solani from potato were characterized previously (24). No introns were observed in the cytochrome $b$ of $A$. alternata, whereas four introns at positions A126, G143, V146, and F164 were observed in the cytochrome $b$ of A. solani (24). The high level of identity (>82\%) observed between the sequence of both A. alternata cytochrome $b$ introns (A126 and F164) and their homologs in A. solani leads us to a hypothesis of recombination events within this particular region of the A. alternata genome (unpublished data). Heterogeneity in the cytochrome $b$ gene (isolates with two or three introns) has been described previously in $B$. cinerea from cucumber and tomato (4); however this is the first description of cytochrome $b$ heterogeneity in an imperfect fungus such as Alternaria. Genetic variation of $A$. alternata populations in citrus was documented previously using random amplified polymorphic DNA markers and endo-polygalacturonase gene sequencing (46). Two well-defined phylogenetic lineages were identified in a single grove of Minneola tangelo in Florida (54), revealing an unexpected level of genetic variability within this clonally reproducing species. Nevertheless, the implications of cytochrome $b$ heterogeneity and the genetic diversity of $A$. alternata populations are unknown. Sequence analysis of the cytochrome $b$ gene in several fungal plant pathogens revealed differences in the intron/exon structure among species (20). Furthermore, the presence of a bi-group I intron between amino acids 143 and 144 appears to prevent the G143A mutation in the cytochrome $b(24,25)$. However, our A. alternata population did not have an intron in that location; therefore, the intrinsic risk to evolve G143A mutation is high as observed in this study. Interestingly, the majority of resistant isolates that we evaluated (127 of 161) belong to isolate profile II. However, it is unknown whether cytochrome $b$ structure is related to the evolution of QoI resistance in tangerineinfecting A. alternata, or why the frequency of the mutant allele was higher in isolates carrying two introns. Further studies are needed to elucidate the effect of QoI fungicides on the population structure of both groups of isolates.

In summary, after testing a large collection of A. alternata isolates for azoxystrobin and pyraclostrobin sensitivity, we concluded that QoI resistance is widespread in Florida and a real concern for tangerine producers. QoI-control failure detected in some groves was produced by the dominance of a resistant population possessing the amino acid substitution G143A. Therefore, regardless of ABS susceptibility, growers must be careful with the use of QoI fungicides to avoid the selection and development of resistance, especially in orchards where resistance has not yet been identified. Our study also identified two groups of isolates with different cytochrome $b$ gene structures, where the majority of resistant isolates were in the group carrying two introns. Finally, more effective disease management strategies, such as rotation of fungicides with different modes of action and the exclusion of QoI fungicides where resistance has been detected, are fundamental in ABS control programs. Newer fungicides (difenoconazole and boscalid) in mixtures with QoI have been registered recently and can be used in rotation with copper and ferbam for ABS control. However, further research is needed to establish baseline sensitivities for those new active ingredients so that they can be monitored for resistance development.

\section{Acknowledgments}

This research was supported by funds from Citrus Research and Development Foundation (CRDF) grant number 519. We thank Syngenta Crop Protection and BASF Crop Protection for material support, L. W. Timmer for critically reading this manuscript, and all the citrus growers who allowed us to collect samples in their orchards.

\section{Literature Cited}

1. Akimitsu, K. A., Peever, T. L., and Timmer, L. W. 2003. Molecular, ecological and evolutionary approaches to understanding Alternaria diseases of citrus. Mol. Plant Pathol. 4:435-446.

2. Amiri, A., Brannen, P. M., and Schnabel, G. 2010. Reduced sensitivity in Monilinia fructicola field isolates from South Carolina and Georgia to respiration inhibitor fungicides. Plant Dis. 94:737-743.

3. Avila-Adame, C., and Köller, W. 2003. Characterization of spontaneous mutants of Magnaporthe grisea expressing stable resistance to the Qo-inhibiting fungicide azoxystrobin. Curr. Genet. 42:332-338.

4. Banno, S., Yamashita, K., Fukumori, F., Okada, K., Uekusa, H., Takagaki, M., Kimura, M., and Fujimura, M. 2009. Characterization of QoI resistance in Botrytis cinerea and identification of two types of mitochondrial cytochrome $b$ gene. Plant Pathol. 58:120-129.

5. Bartlett, D. W., Clough, J. M., Godfrey, C. R., Godwin, J. R., Hall, A. A., Heaney, S. P., and Maund, S. J. 2001. Understanding the strobilurin fungicides. Pestic. Outlook 12:143-148.

6. Bartlett, D. W., Clough, J. M., Godwin, J. R., Hall, A. A., Hamer, M., and Parr-Dobrzanski, B. 2002. The strobilurin fungicides. Pest Manage. Sci. 58:649-662.

7. Bennett, J. W., and Lasure, L. L. 1991. Growth media. Pages 444-445 in: More Gene Manipulations in Fungi. J. Bennett and L. Lasure, eds. Academic Press Inc., San Diego, CA.

8. Bhatia, A., Roberts, P. D., and Timmer, L. W. 2003. Evaluation of the AlterRater model for timing of fungicide applications for control of Alternaria brown spot of citrus. Plant Dis. 87:1089-1093.

9. Bolton, M. D., Rivera, V., and Secor, G. 2013. Identification of the G143A mutation associated with QoI resistance in Cercospora beticola field isolates from Michigan, United States. Pest Manage. Sci. 69:35-39.

10. Bradley, C. A., and Pedersen, D. K. 2010. Baseline sensitivity of Cercospora zeae-maydis to quinone outside inhibitor fungicides. Plant Dis. 95:189-194.

11. Brent, K. J., and Hollomon, D. W. 2007. Fungicide resistance in crop pathogens: how can it be managed? FRAC Monogr. No. 1. Croplife International, Brussels.

12. Canihos, Y., Peever, T. L., and Timmer, L. W. 1999. Temperature, leaf wetness, and isolate effects on infection of Minneola tangelo leaves by Alternaria sp. Plant Dis. 83:429-433.

13. Chin, K. M., Chavaillaz, D., Kaesbohrer, M., Staub, T., and Felsenstein, F. G. 2001. Characterizing resistance risk of Erysiphe graminis f. sp. tritici to strobilurins. Crop Prot. 20:87-96.

14. Corio-Costet, M.-F., Dufour, M.-C., Cigna, J., Abadie, P., and Chen, W.-J. 2011. Diversity and fitness of Plasmopara viticola isolates resistant to QoI fungicides. Eur. J. Plant Pathol. 129:315-329.

15. Dalkilic, Z., Timmer, L. W., and Gmitter, F. G. 2005. Linkage of an Alternaria disease resistance gene in mandarin hybrids with RAPD fragments. J. Am. Soc. Hortic. Sci. 130:191-195.

16. Dewdney, M. M. 2013. Alternaria brown spot. Pages 89-91 in: Florida Citrus Pest Management Guide. Univ. Fla. Inst. Food Agric. Sci. Gainesville.

17. Fernández-Ortuño, D., Chen, F., and Schnabel, G. 2012. Resistance to pyraclostrobin and boscalid in Botrytis cinerea isolates from strawberry 
fields in the Carolinas. Plant Dis. 96:1198-1203.

18. Fernández-Ortuño, D., Tores, J. A., de Vicente, A., and Pérez-García, A. 2008. Mechanisms of resistance to QoI fungicides in phytopathogenic fungi. Int. Microbiol. 11:1-9.

19. Fernández-Ortuño, D., Tores, J. A., de Vicente, A., and Pérez-García, A. 2008. Field resistance to QoI fungicides in Podosphaera fusca is not supported by typical mutations in the mitochondrial cytochrome $b$ gene. Pest Manage. Sci. 64:694-702.

20. Fisher, N., and Meunier, B. 2008. Molecular basis of resistance to cytochrome $b c 1$ inhibitors. FEMS Yeast Res. 8:183-192.

21. Florida Agricultural Statistics Service. 2012. Citrus Summary, 2010-2011. U.S. Dep. Agric. Mark. Serv. Natl. Agric. Stat. Serv. Tallahassee, FL.

22. Fungicide Resistance Action Committee (FRAC). 2013. List of plant pathogenic organisms resistant to disease control agents. Online publication. http://www.frac.info

23. Gardner, J. M., Kono, Y., and Chandler, J. L. 1986. Bioassay and host-selectivity of Alternaria citri toxins affecting rough lemon and mandarins. Physiol. Mol. Plant Pathol. 29:293-304.

24. Grasso, V., Palermo, S., Sierotzki, H., Garibaldi, A., and Gisi, U. 2006. Cytochrome $b$ gene structure and consequences for resistance to Qo inhibitor fungicides in plant pathogens. Pest Manage. Sci. 62:465-472.

25. Grasso, V., Sierotzki, H., Garibaldi, A., and Gisi, U. 2006. Characterization of the cytochrome $b$ gene fragment of Puccinia species responsible for the binding site of QoI fungicides. Pestic. Biochem. Physiol. 84:72-82.

26. Hutton, D. G., and Mayers, P. E. 1988. Brown spot of Murcott tangor caused by Alternaria alternata in Queensland. Australas. Plant Pathol. 17:69-73.

27. Ishii, H. 2009. QoI fungicide resistance: current status and the problems associated with DNA-based monitoring. Pages 37-45 in: Recent Developments in Management of Plant Diseases. U. Gisi, I. Chet, and M. Gullino, eds. Springer, Dordrecht, The Netherlands.

28. Ishii, H., Fraaije, B. A., Sugiyama, T., Noguchi, K., Nishimura, K., Takeda, T., Amano, T., and Hollomon, D. W. 2001. Occurrence and molecular characterization of strobilurin resistance in cucumber powdery mildew and downy mildew. Phytopathology 91:1166-1171.

29. Jiang, J., Ding, L., Michailides, T. J., Li, H., and Ma, Z. 2009. Molecular characterization of field azoxystrobin-resistant isolates of Botrytis cinerea. Pestic. Biochem. Physiol. 93:72-76.

30. Karaoglanidis, G. S., Luo, Y., and Michailides, T. J. 2010. Competitive ability and fitness of Alternaria alternata isolates resistant to QoI fungicides. Plant Dis. 95:178-182.

31. Kim, Y.-S., Dixon, E. W., Vincelli, P., and Farman, M. L. 2003. Field resistance to strobilurin (QoI) fungicides in Pyricularia grisea caused by mutations in the mitochondrial cytochrome $b$ gene. Phytopathology 93:891-900.

32. Kohmoto, K., Akimitsu, K., and Otani, H. 1991. Correlation of resistance and susceptibility of citrus to Alternaria alternata with sensitivity to hostspecific toxins. Phytopathology 81:719-722.

33. Kohmoto, K., Itoh, Y., Shimomura, N., Kondoh, Y., Otani, H., Kodama, M., Nishimura, S., and Nakatsuka, S. 1993. Isolation and biological activities of two host-specific toxins from the tangerine pathotype of Alternaria alternata. Phytopathology 83:495-502.

34. Kohmoto, K., Scheffer, R. P., and Whiteside, J. O. 1979. Host-selective toxins from Alternaria citri. Phytopathology 69:667-671.

35. Köller, W., Parker, D., Turechek, W., Avila-Adame, C., and Cronshaw, K. 2004. A two-phase resistance response of Venturia inaequalis populations to the QoI fungicides kresoxim-methyl and trifloxystrobin. Plant Dis. 88:537-544.

36. Leroux, P., Gredt, M., Leroch, M., and Walker, A.-S. 2010. Exploring mechanisms of resistance to respiratory inhibitors in field strains of Botrytis cinerea, the causal agent of gray mold. Appl. Environ. Microbiol.76:66156630.

37. Lesniak, K. E., Proffer, T. J., Beckerman, J. L., and Sundin, G. W. 2011. Occurrence of QoI resistance and detection of the G143A mutation in Michigan populations of Venturia inaequalis. Plant Dis. 95:927-934.

38. Lu, Y. L., Sutton, T. B., and Ypema, H. 2003. Sensitivity of Alternaria mali from North Carolina apple orchards to pyraclostrobin and boscalid. (Abstr.) Phytopathology 93:S54.

39. Luo, Y., Ma, Z., Reyes, H. C., Morgan, D. P., and Michailides, T. J. 2007. Using real-time PCR to survey frequency of azoxystrobin-resistant allele G143A in Alternaria populations from almond and pistachio orchards in
California. Pestic. Biochem. Physiol. 88:328-336.

40. Ma, Z., Felts, D., and Michailides, T. J. 2003. Resistance to azoxystrobin in Alternaria isolates from pistachio in California. Pestic. Biochem. Physiol. 77:66-74.

41. Miles, L. A., Miles, T. D., Kirk, W. W., and Schilder, A. M. C. 2012. Strobilurin (QoI) resistance in populations of Erysiphe necator on grapes in Michigan. Plant Dis. 96:1621-1628.

42. Mondal, S. N., Bhatia, A., Shilts, T., and Timmer, L. W. 2005. Baseline sensitivities of fungal pathogens of fruit and foliage of citrus to azoxystrobin, pyraclostrobin, and fenbuconazole. Plant Dis. 89:1186-1194.

43. Mondal, S. N., Godoy da Silva, A., and Dewdney, M. M. 2009. Resistance to strobilurin fungicides in a population of Alternaria alternata causing Alternaria brown spot of citrus. (Abstr.) Phytopathology 99:S88.

44. Pasche, J. S., Wharam, C. M., and Gudmestad, N. C. 2004. Shift in sensitivity of Alternaria solani in response to QoI fungicides. Plant Dis. 88:181187.

45. Peever, T. L., Canihos, Y., Olsen, L., Ibañez, A., Liu, Y. C., and Timmer, L. W. 1999. Population genetic structure and host specificity of Alternaria spp. causing brown spot of Minneola tangelo and rough lemon in Florida. Phytopathology 89:851-860.

46. Peever, T. L., Ibañez, A., Akimitsu, K., and Timmer, L. W. 2002. Worldwide phylogeography of the citrus brown spot pathogen, Alternaria alternata. Phytopathology 92:794-802.

47. Peever, T. L., Olsen, L., Ibañez, A., and Timmer, L. W. 2000. Genetic differentiation and host specificity among populations of Alternaria spp. causing brown spot of grapefruit and tangerine $\times$ grapefruit hybrids in Florida. Phytopathology 90:407-414.

48. Rebollar-Alviter, A., Madden, L. V., Jeffers, S. N., and Ellis, M. A. 2007. Baseline and differential sensitivity to two QoI fungicides among isolates of Phytophthora cactorum that cause leather rot and crown rot on strawberry. Plant Dis. 91:1625-1637.

49. Rosenzweig, N., Atallah, Z., Olaya, G., and Stevenson, W. 2008. Evaluation of QoI fungicide application strategies for managing fungicide resistance and potato early blight epidemics in Wisconsin. Plant Dis. 92:561-568.

50. Russell, P. E. 2004. Sensitivity baselines in fungicide resistance research and management. FRAC Monogr. No. 3. Croplife International, Brussels.

51. Sierotzki, H., Frey, R., Wullschleger, J., Palermo, S., Karlin, S., Godwin, J., and Gisi, U. 2007. Cytochrome $b$ gene sequence and structure of Pyrenophora teres and P. tritici-repentis and implications for QoI resistance. Pest Manage. Sci. 63:225-233.

52. Sierotzki, H., Parisi, S., Steinfeld, U., Tenzer, I., Poirey, S., and Gisi, U. 2000. Mode of resistance to respiration inhibitors at the cytochrome $b c 1$ enzyme complex of Mycosphaerella fijiensis field isolates. Pest Manage. Sci. 56:833-841

53. Solel, Z., and Kimchi, M. 1997. Susceptibility and resistance of citrus genotypes to Alternaria alternata pv. citri. J. Phytopathol. 145:389-391.

54. Stewart, J. E., Thomas, K. A., Lawrence, C. B., Dang, H. X., Pryor, B. M., Timmer, P., and Peever, T. 2013. Signatures of recombination in clonal lineages of the citrus brown spot pathogen, Alternaria alternata sensu lato. Phytopathology 103:741-749.

55. Timmer, L. W. 2000. The Alter-Rater. A new weather-based model for timing fungicide sprays for Alternaria control. Citrus Ind. 82:23-24

56. Timmer, L. W., Darhower, H. M., Zitko, S. E., Peever, T. L., Ibanez, A. M. and Bushong, P. M. 2000. Environmental factors affecting the severity of Alternaria brown spot of citrus and their potential use in timing fungicide applications. Plant Dis. 84:638-643.

57. Timmer, L. W., and Peever, T. L. 1997. Managing Alternaria brown spot. Citrus Ind. 79:24-25.

58. Timmer, L. W., Peever, T. L., Solel, Z., and Akimitsu, K. 2003. Alternaria diseases of citrus-novel pathosystems. Phytopathol. Mediterr. 42:99-112.

59. Timmer, L. W., Solel, Z., Gottwald, T. R., Ibanez, A. M., and Zitko, S. E. 1998. Environmental factors affecting production, release, and field populations of conidia of Alternaria alternata, the cause of brown spot of citrus. Phytopathology 88:1218-1223.

60. Vega, B., Liberti, D., Harmon, P. F., and Dewdney, M. M. 2012. A rapid resazurin-based microtiter assay to evaluate QoI sensitivity for Alternaria alternata isolates and their molecular characterization. Plant Dis. 96:1262 1270.

61. Ypema, H., and Gold, R. 1999. Kresoxim-methyl: modification of a naturally occurring compound to produce a new fungicide. Plant Dis. 83:4-19. 